\title{
Risk Allocation in Toll Highway Concessions in Spain Lessons from Economic Recession
}

\author{
José Manuel Vassallo, Alejandro Ortega, and María de los Ángeles Baeza
}

Spain has a long tradition of encouraging toll highways by granting concessions to private companies. Concessions in Spain have been characterized by a willingness to transfer considerable risk to the private sector. Traffic demand, acquisition of the right-of-way, and financial risk have often been allocated to the private sector. From 1996 to 2011, 16 toll highway concessions, covering a total distance of $835 \mathrm{~km}$, were awarded by the central government of Spain with this approach. Some of those highways started their operations just before the economic recession began. The recession had negative consequences for Spain's economy. The gross domestic product per capita plummeted, and the unemployment rate increased from $9 \%$ to $20 \%$ of the working population in just 2 years. The recession also had severe consequences for the economic performance of toll highway concessions. Traffic levels declined at a much greater rate than did the gross domestic product. In addition, the conditions imposed by the financial markets on borrowers became much stricter because of the liquidity crisis. This study analyzes the impact that the economic recession ultimately had on the performance of toll highway concessions in Spain and the actions that the government adopted to avoid the bankruptcy of the concessionaires. It was found that the economic recession helped identify some deficiencies in how risk had been allocated in Spain. The measures that both Spain and the European Union are adopting so as to improve risk allocation are discussed.

Since the adoption of the single currency in 1999 and until 2007, Spain kept up its steady economic development, which resulted in annual average growth in the gross domestic product (GDP) that was consistently above the average for the European Union (EU). During this period, public infrastructure investment reached the highest levels ever seen in the history of Spain. In fact, the ratio of public investment to GDP in Spain became one of the highest among the EU countries.

One of the key mechanisms that helped advance infrastructure investment in Spain was the implementation of different public-

J. M. Vassallo and A. Ortega, Transportation Department, Universidad Politécnica de Madrid, Departamento de Transportes, ETSI de Caminos, Canales y Puertos, Profesor Aranguren s/n, 28040 Madrid, Spain. M. de los Ángeles Baeza, Facultad de Ciencias Económicas y Empresariales, Departamento de Economía Financiera y Contabilidad, Universidad de Granada, Campus Universitario de Cartuja s/n, 18071 Granada, Spain. Corresponding author: J. M. Vassallo, jvassallo@caminos. upm.es.

Transportation Research Record: Journal of the Transportation Research Board, No. 2297, Transportation Research Board of the National Academies, Washington,

D.C., 2012, pp. 80-87.

DOI: 10.3141/2297-10 private-partnership (PPP) approaches. Among them, the use of concession contracts awarded for the building and maintenance of toll highways - which have a long tradition in the Spanish legal framework to encourage private companies to participate in the design, construction, maintenance, and operation of toll highwayswas widespread. This approach was based on transferring most of the risk (costs of land expropriation, construction, traffic revenues, interest rate, and other financial risks) to the private sector. From the beginning, highway concessions in Spain were competitively awarded to private consortia through competitive tenders. This practice is substantially different from the situation in other European countries such as France and Italy, which directly entrusted toll highways to public-private companies mainly controlled by the government.

The objective of this study is threefold. First, the consequences of the economic recession that struck Spain beginning in 2008 on the outcome of the concession contracts are assessed, especially on traffic levels and the requirements imposed by financial institutions for providing project finance loans. Second, the weaknesses of the Spanish toll highway concession approach are analyzed, which became apparent as a consequence of the economic recession and the financial crisis. Third, the current trends in both Spain and Europe toward a greater role for the public sector in mitigating risk in PPP contracts and supporting big PPP deals through guarantees and subordinated debt are described.

\section{TOLL HIGHWAY CONCESSIONS IN SPAIN}

\section{Historical Evolution}

Toll highway concessions in Spain have a long track record. Three different periods regarding the implementation of highway concessions in Spain can be distinguished: 1967 to 1975, 1976 to 1995, and 1996 to the present $(1)$.

Between 1967 and 1975, 2,042 km of toll highways was built by the central government of Spain. A toll highway program was started as a means of expanding and improving the Spanish highway network because the Spanish state was not able to afford such a huge investment. Private funding was the only means available to reach that goal $(1,2)$.

The second stage dates from 1976 to 1995 . In this period, no highway concession was awarded. The Socialist government, which took office in 1982 and remained in power until 1996, was politically opposed to promoting private concessions as a means to finance highways. Instead, the government opted for modernizing the Spanish road network by widening and upgrading the most important roads. This new program was completely funded by the public sector. 
The third stage began in 1996 and continues up to the present. In 1996 the conservative People's Party took office in Spain. The need to contain Spain's public deficit was the most difficult challenge facing the new government. This problem was the main reason why the new government decided to implement once again the policy of offering concessions so as to encourage the participation of the private sector in the financing of new transportation infrastructure. The Socialist government that took office in 2004 by now shared this faith in the concession system, though it promoted fewer toll highways than had the People's Party when it was in power. From 1996 up to $2011,835 \mathrm{~km}$ of new toll highway concessions was awarded by the central government of Spain through this approach.

\section{Legal Framework}

The legal framework for PPPs in Spain has evolved significantly over the years. The first highway concessions were awarded on the basis of specific decrees passed by the government. In 1972 the first law, called the Toll Highway Law, was passed. The goal of this law was to regulate toll highway concession contracts and the public guarantees applicable to them.

However, the most important legislation about concession contracts in Spain occurred with the approval of the public works concession law in 2003. This law was promptly incorporated into the framework of the public contract law. One of the law's objectives was to update the old highway concession model and to extend it to all types of public works to reinforce the contribution of private financing for the construction and maintenance of public facilities and to define a new risk-sharing approach (3).

In 2007 a new public contract law was passed in Spain in order to transpose new EU legislation concerning public contracts to the Spanish legal framework. This new law basically maintained the legal framework set up in 2003 regarding concession contracts, though some slight modifications were incorporated.

\section{Main Features of Concession Contracts}

Toll highway concessions in Spain have retained most of their distinctive features throughout the years, even though there are some differences between the concessions awarded in the first period and those awarded in the third period. Procurement of highway concessions in Spain has been done largely on the basis of an "open procedure." This procedure means that any company that fulfils the minimum requirements as set out by the government in the contract's provisions is allowed to participate in the tendering process. Unlike other long-term infrastructure contracts in the world (e.g., design-buildfinance-operate contracts in the United Kingdom and most of the PPP contracts in Germany), concession contracts in Spain were not agreed on in negotiations between the government and the bidders. Rather, the government submits standard contracts to the bidders through the bidding terms it sets that eventually will have to be accepted by all the concessionaires. The bidders are not allowed to introduce additional clauses to clarify specific events that might eventually happen.

The concession contracts in Spain are consequently rather incomplete since they are not negotiated for each project. However, transaction costs for both bidders and the government are very low in Spain as compared with other countries (4). This feature is probably the most important reason why the number of bidders participating in the tendering processes for highway concessions in Spain is often quite large (1).

Another feature of concession tenders in Spain is that although the government requires the bidders to submit a business plan in their offers, the government does not require that they reach a financial close before the contract is awarded.

For toll highways, maximum toll levels are set up in the contract for each of the preestablished vehicle categories. According to the contract, the tolls are updated every year to bring them into line with inflation. The contracts permit the concessionaires a certain flexibility in reducing the tolls outside of the peak hours.

Another innovation recently introduced in Spain is the so-called "progress clause." This clause consists of requiring the concessionaire to maintain and operate the public works according to the technical, environmental, and safety regulations that are currently in force and applicable. The aim of this clause is to guarantee that the concessionaire is going to adequately maintain and operate the highway throughout the years. For instance, if a new regulation varies the standards of the safety barriers, the concessionaire has the obligation to upgrade the barriers according to the new standards at its own cost. Since the implementation of this clause in 2003, the technological risk has been transferred to the private sector.

\section{RISK ALLOCATION IN CONCESSIONS}

\section{General Principles}

Risk in concession contracts reflects the inability of the stakeholders to know in advance the change in the variables that determines the value of the concession business throughout the life of the contract. As pointed out by Pinglo et al., concession contracts are regarded by the private sector as an attractive but highly risky business (5). Concession contracts are also risky for the government in that public guarantees by the government are provided.

Toll motorway concessions undergo several types of risk. These risks can be classified in two different ways. According to their relative influence in the economic balance of the contract, the following can be identified: capital cost risk (land acquisition, construction and license approval), revenue risk, and maintenance and operation risk. According to the nature of the risk, the risks can be classified into three types: market risk, unpredictable risk, and legal and political risk (2).

The last classification can be narrowed down into two types of risk: global risk and project risk. Global risk is completely unpredictable, such as earthquakes, terrorist acts, or changes in the government, and is impossible to anticipate at the time the contract is drafted. Project risk is those risks, such as construction risk, operation risk, or availability risk, that are manageable in a certain way by the project operator (6).

There is extensive literature regarding risk allocation in concession contracts $(7,8)$. According to the World Bank, the allocation of risks in concession contracts should be made according to two criteria (9): (a) the risk should be allocated to the stakeholder best able to manage the risk outcome and $(b)$ the risk should be borne by the stakeholder best able to handle the risk at the lowest cost. Market risks are usually allocated to the concessionaire, whereas the government often assumes unpredictable political and legislative risks.

Risk allocation has a direct and important bearing on the financial cost of the project. When the risks allocated to the concessionaire are very high, the financial cost of the project becomes significant and can threaten the ultimate financial feasibility of the project. For that reason, public guarantees are often provided. These guarantees 
facilitate the financial feasibility of the project through the allocation of greater risk to the government.

An adequate risk allocation profile in PPPs requires striking the right balance between risks retained by the public sector and risks transferred to the private sector. Too much risk retained by the public sector might not encourage the concessionaire to perform properly and might end up proving to be too costly for the public budget in the future. In its turn, too much risk transferred to the private sector might make the project infeasible from the financial standpoint of attracting private investors.

\section{Risk Allocation Before Financial Crisis}

Risk allocation in toll concession contracts in Spain has evolved slightly over the years. The first concession contracts awarded in Spain allocated most of the market risk to the private sector (both concessionaires and financial institutions). In spite of that feature, the government granted certain fiscal advantages and financial guarantees to the concessionaires in order to attract funding for such projects from financial institutions and other investors.

The two oil shocks that the industrialized countries experienced in the 1970s had a huge impact on the guarantees provided by the Spanish government to highway concessionaires in two ways. First, the rise in gas prices caused traffic growth to be lower than expected. Second, exchange rates became unusually unstable. These factors triggered the guarantees that had been incorporated in the already existing contracts, which ultimately became very expensive for the government.

Because of the problems mentioned earlier, further legislation considerably restricted public guarantees, even though it incorporated several mechanisms whereby the public sector could eventually contribute to the financial feasibility of concession contracts. The current concession law establishes that the private sector should be allocated most of the market risk (3). However, it allows for compensating the concessionaire by changing the economic balance of the contract in three circumstances:
- When the government imposes additional changes to the original contract terms so as to favor the public interest, for example, additional work required of the concessionaire to improve safety on the highways;

- When the government carries out actions not foreseen when the contract was signed that substantially affect the economics of the contract, for example, a change in the corporate tax rate or the construction of competing infrastructure not originally foreseen; and

- When circumstances of force majeure (defined by Spanish legislation as fire caused by atmospheric electricity, natural phenomena with catastrophic implications, and damage caused by war and serious alterations of the public order) lead directly to substantial disruption of the financial terms of the concession.

In addition, Spanish law allows, but does not require, the contracting parties to set up a procedure to mitigate risk by setting up minimum and maximum thresholds in the terms for any variable related to the financial result of the concession (traffic, revenues, and so forth), as defined in the bidding terms. Unfortunately, this measure has rarely been adopted. The current financial problems of most of the concessions awarded during the third period would not have been that big if these mechanisms had been implemented.

Table 1 shows how risks are allocated in toll highway concession contracts in Spain compared with the recommendations included in a report by the Organization for Economic Cooperation and Development (OECD) (6). Risk allocation in Spain turns out to be much more dependent on the private sector than these recommendations. The government bears little risk since the Spanish law states that force majeure and policy risks will be covered by changes in the economic balance of the concession contract, which does not necessarily require contributions from the government.

The most important risk borne by the government in Spain is the project default risk. One of the most controversial clauses of the Spanish concession law regarding risk allocation is the one that determines the compensation to the concessionaire in case of early termination of the contract. This clause, which does not exist in the United States, establishes that if the contract terminates earlier than

TABLE 1 Risk Allocation in Toll Highway Concessions Compared with Recommendations from OECD

\begin{tabular}{|c|c|c|c|}
\hline Risk Category & Example & Risk Allocation & $\begin{array}{l}\text { Partner Likely Well Suited } \\
\text { to Manage Risk }{ }^{a}\end{array}$ \\
\hline Force majeure & Loss from war and natural disaster & $\begin{array}{l}\text { Change in economic balance } \\
\text { of contract }\end{array}$ & Public \\
\hline Regulatory and political risk & $\begin{array}{l}\text { Project delay, change in law or policy affecting } \\
\text { revenue } \\
\text { Land acquisition }\end{array}$ & $\begin{array}{l}\text { Change in economic balance } \\
\text { of contract } \\
\text { Private }\end{array}$ & Public \\
\hline Revenue-demand risk & $\begin{array}{l}\text { Deficient revenue due to low traffic volume or lower } \\
\text { price due to demand elasticity }\end{array}$ & Private & Mostly public, some private \\
\hline Design-technical risk & Engineering or design failure & Private & Private \\
\hline Construction risk & Cost escalation due to delay or faulty technique & Private & Private \\
\hline Operating risk & $\begin{array}{l}\text { Costly operation and life-cycle } \\
\text { maintenance }\end{array}$ & Private & Private \\
\hline Environmental risk & $\begin{array}{l}\text { Damage and liability or mitigation cost from adverse } \\
\text { environmental events }\end{array}$ & Private & Private \\
\hline Financial risk & $\begin{array}{l}\text { Cost of inadequate revenue hedging and debt } \\
\text { management }\end{array}$ & $\begin{array}{l}\text { Private } \\
\text { Subordinated public participation } \\
\quad \text { loans }\end{array}$ & Mostly private, some public \\
\hline Project default risk & Project bankruptcy from any or all of the factors above & Mostly public & Shared public and private \\
\hline
\end{tabular}

${ }^{a}$ Recommendations from the OECD 
it is supposed to-and bankruptcy is one of the causes of such early termination of the contract - the government will have to pay compensation to the concessionaire equal to the capital cost declared by the concessionaire in its financial plan minus the depreciation of the assets calculated according to the accounting norms of Spain. Regardless of the principle under which this guarantee is based, the fact is that this guarantee may have serious negative consequences for the government since the committed payments will immediately increase the size of the public deficit of Spain. This clause poses the problem that it gives the concessionaire a lot of bargaining power to put pressure on the government to renegotiate the concession contract. This clause was not changed when the new law was drafted because no alternative was found by the government to mitigate the lenders' risk in case of early termination of the contract.

The financial risk falls primarily on the private sector. Consequently, the government does not provide guarantees in case events prompting unusual changes in the financial markets eventually occur. Regardless, the government can provide subordinated public participation loans (SPPLs) to improve the financial feasibility of concession projects (1). SPPLs are loans provided by the government that are subordinated to senior debt. Consequently, participating loan holders (which is the government in the case of SPPLs) will be paid back only after the concessionaire has met its obligations to the senior lenders. However, the participating loan holders will be paid back before the shareholders receive any dividend.

The expected rate of return of SPPLs is related to the performance of the concession. In other words, the better the outcome of the concession-in terms of traffic, sales, revenues, or whatever other variable may be specified in the contract - the greater the rate of return of the SPPLs. The idea behind this approach is that the government shares the profits and losses of the project with the concessionaire.

\section{IMPACT OF ECONOMIC RECESSION ON HIGHWAY CONCESSIONS}

\section{Causes and Consequences of Recession}

The economic recession in Spain has been caused by both exogenous and endogenous factors. The most important exogenous causes are the price rise of raw materials (such as copper and oil) and the influence of the global financial crisis. The endogenous causes are also two: the real estate bubble that damaged the financial system because

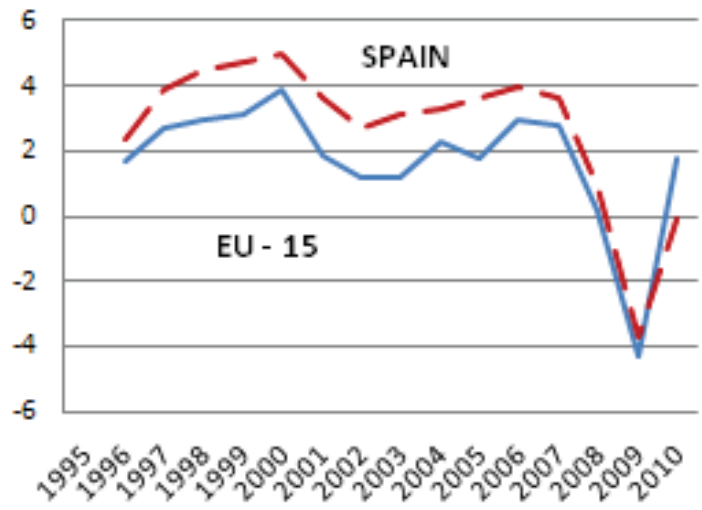

(a) of the great exposure of the Spanish banks to mortgages and the limited capacity of Spain to respond to the crisis because of the low productivity of the Spanish workforce, the lack of flexibility in the labor market, and a high level of indebtedness in both the public and the private sectors $(10)$.

The impact of the economic crisis in Spain has been one of the most severe among the European countries. The country was in recession for seven straight quarters, which was reflected in negative GDP growth in both 2009 and 2010. This impact provoked an accelerated increase in the unemployment rate, which in 2010 surpassed 20\%, the highest among the first 15 countries to join the European Union (EU-15). In this same year Germany and France, by contrast, had unemployment rates of $7 \%$ and $9.7 \%$, respectively.

Figure 1 shows the evolution over time of some key macroeconomic indicators comparing Spain with the EU-15. It can be seen how the recession struck Spain much more sharply than it did the rest of the EU-15 in terms of reduction of GDP growth and the growth of the unemployment rate.

A report prepared by the Bank of Spain (11) claimed that the recovery of Spain will be slow and strongly dependent on the evolution of the broader European economy. Estimates for 2011 forecast a GDP growth of around $1 \%$ accompanied by an inflation rate of more than $2.5 \%$. These forecasts seem to indicate that the crisis will take much longer to end than originally forecast. Moreover, in 2011 the EU had set up higher interest rates for the euro than the Spanish economy needed.

\section{Impacts on Toll Highway Concessions}

The economic recession has affected toll highway concession contracts in Spain in two ways: first, a substantial reduction of real traffic levels compared with the expected levels and second, a substantial tightening of the requirements demanded by financial institutions if they are to grant loans.

\section{Impact on Real Traffic Levels}

Table 2 shows yearly traffic growth in the toll highway concessions awarded from 1996 on as compared with the annual GDP growth in Spain. From the analysis of Table 2, it can be appreciated how traffic growth before the onset of the economic recession was for almost

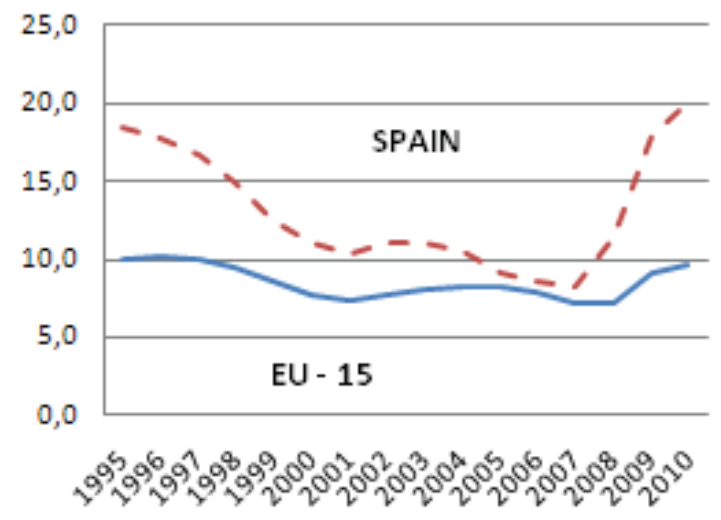

(b)

FIGURE 1 Evolution of $(a)$ real GDP growth and $(b)$ unemployment rate. 
TABLE 2 Traffic Growth in Toll Concessions Compared with GDP Growth

\begin{tabular}{|c|c|c|c|c|c|c|c|c|c|}
\hline \multirow[b]{2}{*}{ Toll Highway } & \multirow[b]{2}{*}{$\begin{array}{l}\text { First Year of } \\
\text { Operation }\end{array}$} & \multicolumn{2}{|c|}{ 1st Year of Operation, 2007} & \multicolumn{2}{|l|}{$2007-2008$} & \multicolumn{2}{|l|}{ 2008-2009 } & \multicolumn{2}{|l|}{ 2009-2010 } \\
\hline & & $\begin{array}{l}\text { Real GDP } \\
\text { Growth (\%) }\end{array}$ & $\begin{array}{l}\text { Traffic } \\
\text { Growth } \\
\text { (\%) }\end{array}$ & $\begin{array}{l}\text { Real GDP } \\
\text { Growth } \\
(\%)\end{array}$ & $\begin{array}{l}\text { Traffic } \\
\text { Growth } \\
(\%)\end{array}$ & $\begin{array}{l}\text { Real GDP } \\
\text { Growth } \\
(\%)\end{array}$ & $\begin{array}{l}\text { Traffic } \\
\text { Growth } \\
(\%)\end{array}$ & $\begin{array}{l}\text { Real GDP } \\
\text { Growth } \\
(\%)\end{array}$ & $\begin{array}{l}\text { Traffic } \\
\text { Growth } \\
(\%)\end{array}$ \\
\hline Málaga-Estepona-Guadiaro & 1999 & 3.73 & 6.40 & 0.9 & -5.95 & -3.7 & -8.19 & -0.1 & -3.7 \\
\hline Alicante-Cartagena & 2001 & 3.41 & 9.70 & 0.9 & -8.75 & -3.7 & -8.93 & -0.1 & 1.5 \\
\hline Ávila-Villacastín & 2002 & 3.38 & 6.50 & 0.9 & -1.24 & -3.7 & 17.28 & -0.1 & -0.85 \\
\hline Santiago-Alto de Santo Domingo & 2003 & 3.52 & 13.50 & 0.9 & 3.65 & -3.7 & 3.2 & -0.1 & 5.01 \\
\hline Segovia-El Espinar & 2003 & 3.52 & 5.90 & 0.9 & -3.24 & -3.7 & 5.82 & -0.1 & 4.11 \\
\hline León-Astorga & 2003 & 3.52 & 2.60 & 0.9 & 4.37 & -3.7 & -4.34 & -0.1 & -4 \\
\hline$R-2$ Madrid-Guadalajara & 2003 & 3.52 & 8.80 & 0.9 & -3.99 & -3.7 & -11.48 & -0.1 & -1.06 \\
\hline R-3 Madrid-Arganda & 2004 & 3.62 & 15.00 & 0.9 & -4.19 & -3.7 & -4.54 & -0.1 & -5.18 \\
\hline R-5 Madrid-Navalcarnero & 2004 & 3.62 & 3.70 & 0.9 & -4.46 & -3.7 & -5.89 & -0.1 & -2.78 \\
\hline R-4 Madrid-Ocaña & 2004 & 3.62 & 22.00 & 0.9 & -8.32 & -3.7 & -15.06 & -0.1 & -8.37 \\
\hline Eje aeropuerto & 2005 & 3.73 & 39.68 & 0.9 & 0.78 & -3.7 & -2.6 & -0.1 & -1.09 \\
\hline Ocaña-La Roda & 2006 & 3.79 & 8.20 & 0.9 & 2.67 & -3.7 & -3.31 & -0.1 & -10.48 \\
\hline Madrid-Toledo & 2006 & 3.79 & -0.10 & 0.9 & -13.32 & -3.7 & -21.57 & -0.1 & -17.1 \\
\hline Cartagena-Vera & 2007 & 3.6 & - & 0.9 & 2.88 & -3.7 & -13.15 & -0.1 & 3.58 \\
\hline Circunvalación de Alicante & 2007 & 3.6 & - & 0.9 & 7.16 & -3.7 & -20.07 & -0.1 & -9.13 \\
\hline
\end{tabular}

NOтE: Toll highways competing with free highways are shown in bold italics; $-=$ not applicable. 
all the concessions much higher than the average GDP growth. This growth may be caused by what is called the "ramp-up" effect (12). This effect means that during the first few years after new infrastructure is opened, it has fewer users than it would have had if the users were accustomed to the existence of the infrastructure. This effect happens because users need a certain period of time to familiarize themselves with the existence of new infrastructure and its effect within the transportation network.

However, the trend just described changed, and reversed, when the economic recession began. Most of the concessions experienced traffic reductions much greater than the GDP reduction. This effect can be termed the "clamp-down effect." The effect of the crisis was particularly devastating on the toll highways competing with the free highways (shown in bold italics in Table 2). Most of these toll highways are located in urban areas.

The overall consequence of the changes in traffic levels is that greenfield toll concessions tend to improve their performance over the years if the economy grows positively. However, most of the toll concessions awarded in Spain since 1996 have had to deal with the effects of the economic recession during the ramp-up period, the very period when the greatest traffic growth would be expected.

The traffic revenue issue was made worse in some concessions that compete with free highways because of the high cost overruns in the initial acquisition of the right-of-way. In the case of some of the toll highways giving access to Madrid City (Radial 2, Radial 3, Radial 4, and Radial 5), the concessionaire believed that the value of the land necessary to build them was going to be similar to the cost for rural properties. However, the landowners appealed to the court of justice, and that court eventually resolved matters in favor of the landowners, concluding that the land acquired was located close to the city and that the construction of a new highway raised the value of the land nearby to a greater extent than previously had been assumed by the private parties involved in the concession (13).

\section{Impact of Requirements by Financial Institutions}

Most concession contracts are funded on the project finance basis whereby a special purpose vehicle is created by the sponsors to manage the project. Overall, around $10 \%$ of private-sector infrastructure investment uses this means of project finance, including PPPs (14). The special purpose vehicle will be funded by equity provided by the sponsors and nonrecourse debt provided by financial institutions or capital markets. Most of the debt to fund toll highways in Spain comes from Spanish banks for several reasons. First, unlike the United States, capital markets for project finance deals are not well developed in Spain. Second, commercial banks in Spain have historically been financially strong and are familiar with concession contracts (15).

After the beginning of the world financial crisis, which came right after the bankruptcy of Lehman Brothers in 2008, Spanish banks were affected by the global liquidity crisis, so they became much more restrictive in the loans they provided to highway concessions. Greenfield projects with full traffic risk allocation to the concessionaire were no longer eligible for funding without substantial traffic risk mitigation mechanisms, such as flexible term concession or minimum income guarantees $(16,17)$, being put in place.

Brownfield projects with a long traffic track record and greenfield projects whose revenues come from availability payments were eligible to be funded by the banks with much stricter requirements than before: much greater spreads (from 150 basis points up to 375 basis points), shorter terms (from 25 years down to 7 years), and higher annual debt service coverage ratios (from 1.2 up to 1.5). The impact of the financial recession on the financial cost of highway concessions was enormous.

In addition, banks were no longer willing to provide long-term financing. The debt was provided on the basis of "mini perm" loans with cash sweep guarantee. Mini perms are loans no longer than 7 years, and they have to be refunded once the project has been completed and can therefore start generating income. Consequently, the sponsors run the risk of having to refund the special purpose vehicle once the work has been finished.

As was mentioned earlier, toll highway concessions in Spain are awarded on the basis of an open procedure, which does not require the bidders to reach the financial close before the contract has been awarded. This procedure has the advantage that it is easy for a selected concessionaire to seek the lowest financial cost in the market after being awarded the concession. However, not requiring a financial close in the tender has the disadvantage that no lender actually conducts due diligence of the proposal, so bids are likely to end up being more optimistic. Some of the concessions in Spain were awarded right after the financial recession began, so the concessionaires negotiated the financial contracts with banks imposing much stricter conditions than they had before or than the concessionaires had assumed would be the case. This situation damaged even more the economic attractiveness of some of the concession projects.

\section{Consequences for Government}

The poor economic performance of some concessions, as described earlier, especially that of the suburban toll highway concessions around Madrid, moved the government to adopt some measures to help the concessionaires make their businesses viable. The concessions affected by such mitigation were those for which traffic overestimation turned out to be particularly high and cost overruns caused by land expropriation became onerous for the concessionaires to bear.

The government approved a set of measures in order to mitigate the effects of the recession. The measure adopted by the government was the award of SPPLs to the concessionaires, which the concessionaires will have to pay back to the government in the future.

However, the economic prospects of the concessions were so poor that the award of SPPLs alone to the concessionaires was not enough to make the expected yield of the SPPLs viable. In order to solve this problem, the government changed the contract terms of two of the concessions. The Radial 2 concession - a suburban toll highway that was created to alleviate congestion into and out of Madrid Citywas extended by 14 years and the tolls allowed to be charged by the concessionaire were increased above the levels originally established in the contract. The holder of the concession, which included both Radial 3 and Radial 5-also suburban toll highways in the metropolitan area of Madrid — was also authorized to raise the tolls over the values originally set up in the contract terms.

The aim of changing the original contract terms was to guarantee that the project will be able to pay back the SPPLs provided by the government. This measure has been implemented as well in the Alicante-Cartagena concession. The contract terms of the MálagaAlto de Las Pedrizas concession, which is still in the construction phase, have also been changed by the government through a 17-month extension of the concession's length and through permitting a rise in the tolls above what was originally established in the contract. 
In addition, at the end of 2010 the Parliament approved a law in order to guarantee to the concessions that were not performing well the difference between the $80 \%$ of the revenues originally expected and the revenues actually collected for a period of 3 years. The revenues of most of the toll concessions hover around $50 \%$ and $70 \%$ of the original estimates. The funds provided by the government are actually SPPLs since they are supposed to be paid back to the government with an interest rate equivalent to the one applied in other SPPLs. In 2011 the government disbursed up to $€ 80.1$ million to compensate the concessions whose operations began in 2004 or later and consequently have been particularly harmed by the drop in traffic following the recession.

\section{NEW CONCEPTION OF RISK ALLOCATION IN CONCESSIONS}

The case of toll highway concessions in Spain demonstrates the vulnerability of long-term contracts to unexpected changes in the evolution of the economy. It also demonstrates that, contrary to earlier expectations, transferring most of the risk to the private sector may end up being even worse for the government than if the government had originally retained those risks.

This situation does not mean that PPPs are not a good way of providing for building and maintaining highway infrastructure, but it might mean that the government should play a more important role in mitigating risk in order to foster the financial viability of projects that are good for society. Europe and Spain specifically are moving in this direction. Two initiatives are described, which are already being studied, for creating a better risk-sharing approach in PPPs: the OASIS research project and the infrastructure bond initiative promoted by the European Commission.

\section{New Framework}

The Ministry of Research and Development of the government of Spain entrusted to a consortium made up of universities and companies involved in the highway business the definition of a new framework for highway concessions in Spain. The project, OASIS, is still ongoing. However, some of the proposals derived from this project have already been announced (18).

The project sets up a new institutional framework for highway concessions in Spain. It establishes that the trunk network will be managed through concession contracts with private companies. The concessions will be awarded competitively. The concessionaires will be paid a monthly or a yearly fee related to a set of performancebased indicators such as the state of the pavement, safety, quality of service, and so on.

The government will implement tolls over the trunk network for all types of vehicles. The tolls will be set periodically by the government according to such criteria as the type of road, the time of the day, the congestion level, the type of vehicle, the emission category of the vehicle, and so on. Tolls will be collected by a public agency directly or through a private contractor on its behalf. The money collected will go into an infrastructure fund administered by the government. The resources of this fund will be used to pay the fees to the concessionaires, cover the expenses stemming from the implementation of an electronic toll collection system, and promote transport policies aimed at improving safety and promoting cleaner - that is, less polluting—vehicles.
This approach means that traffic risk will no longer be totally borne by the concessionaires but rather will be substantially borne by the government. The government has some advantages over individual concessionaires in the management of traffic risk. First, it manages a large portfolio of highways; gains and losses from different road stretches can help to balance out the overall picture. Second, the government has greater flexibility to manage toll rates so as to avoid deficits, or, in case of a deficit, it can provide subsidies to the system if that were determined to be the best option. Removing traffic risk from the concessionaire's side also has some problems as long as the concessionaire's incentive to attract traffic can be substantially reduced.

The main advantage of this approach is that concession contracts and their inherent advantages - such as efficiencies from the concessionaire's applying a life-cycle cost perspective and higher quality requirements - are reinforced, whereas traffic and enforcement risks are reallocated to the public sector. Another advantage is that tolls are established in a similar way all over the network so that some sections of the network - the ones with the heaviest traffic —will in effect be subsidizing those that have the lightest traffic, thereby spreading, and minimizing, the overall risk.

\section{Infrastructure Bond Initiative}

Another interesting initiative that is being promoted by the EU to facilitate debt financing of relevant infrastructure projects is the so-called Europe 2020 Project Bond Initiative (19). The Europe 2020 strategy for smart, sustainable, and inclusive growth intends, among other proposals, to foster the participation of private capital in the financing of public infrastructure. This initiative is especially important given the huge amount of infrastructure investment required and the great pressures on government budgets in Europe.

The initiative will be launched by the Commission of the EU together with the European Investment Bank (EIB). The idea behind the Project Bond Initiative is to provide EU support to project companies issuing bonds to finance large-scale infrastructure projects. The initiative would be available to those projects that are judged to be economically and technically sound and cost-effective and that have a real prospect of financial viability.

Infrastructure bonds issued in the EU have rarely proved attractive to a broad investor base. The only way to make these bonds appealing to the financial markets had been to offer them along with the guarantee of monoline insurance. However, with the demise of the monoline industry, such issuance effectively came to an end.

The Project Bond Initiative intends to provide credit enhancement in order to promote the issuance of bonds. This enhancement could take the form of either a debt service guarantee or an additional layer of subordinated debt. The choice of a guarantee or a loan would depend on the precise financial characteristics of each project, but neither would serve as a substitute for shareholder contributions in the form of equity or shareholder loans. The initiative sets up a maximum limit for the guarantee or subordinated debt eligible to be provided. Either the guarantee or the subordinated debt will never exceed $20 \%$ of the senior debt of the project.

The initiative would absorb much of the risk that insufficient cash would be available to service the senior debt, thereby raising its credit rating. This feature will enable senior project debt to be issued in the capital markets in the form of a new class of project bonds, resulting in reduced funding costs for longer maturities for project entities while at the same time meeting the demand of institutional investors (such as pension funds and life insurance companies) for stable, long-term assets. 
The debt service guarantee could be in the form of a contingent credit line provided to the project entity by the EIB (or another financing partner), which would inject funds into the entity if the project were unable to generate sufficient cash in the short to medium term to service its debt for any reason. Once drawn, the facility would be subordinated to the project bonds. The project bonds would be repaid first. Any funds left over would be used to repay the facility through a subordinated cash sweep mechanism.

Alternatively, an EIB subordinated loan of sufficient size could be provided to the project entity, with the same effect as the guarantee just described of increasing the cash flow available to cover the senior project bonds in order to achieve the necessary investment-grade rating required by institutional investors. This second approach resembles the U.S. Transportation Infrastructure Finance Act of 1998 (20).

The EIB will be entrusted with performing the required due diligence and financial appraisal in the structuring phase. This institution will also price the guarantee or loan and thereafter monitor the project. The EU and the EIB will share the risk of the losses of the project portfolio. The risk-taking by the EU and the EIB would be compensated through a risk premium charged up front to the project entity at the time the agreement over the exact terms of the guarantee is concluded.

\section{CONCLUSIONS}

It was shown how the economic recession and financial crisis that started in 2008 have helped identify some of the deficiencies of highway concessions in Spain related to the way risks are allocated. Moreover, the consequences of the economic recession for the performance of toll highways proved that transferring too much risk to private promoters may end up, paradoxically, being worse for the government than if it had always retained part of the risk. This situation happens because when concessions start having problems, the government usually prefers to bail out the concessions to keep them alive rather than allow them to fail and force the government to take over. This occurs even though no legal provision obliges the government to act in this way and to rescue the concessionaires.

From this analysis it is concluded that the economic recession has helped Spain and the EU to be aware of the necessity to change the way risks are being allocated in toll highway concessions. The economic recession has caused those concerned with highway concession contracts to learn three lessons. First, past experience has demonstrated that allocating the bulk of traffic risk to the concessionaires does not work well, particularly for greenfield projects. To solve this problem, new models, which unlink revenue generation in the highway network from fees paid to the concessionaires, are being studied. Second, sudden changes in financial market conditions have demonstrated that the financial close of the project should not be unduly delayed. To solve this problem, the implementation of a deadline in concession contracts to reach the financial close of the project seems to be a good alternative. And third, the severe economic recession has demonstrated the weaknesses of the financial markets in providing long-term financing to megaprojects. To solve this problem, in the future the public sector will have to play a more important role through subordinated debt or financial guarantees to the projects.

With the framework proposed in the OASIS project, the consequences for the concessionaires of the economic recession would not have been so devastating because their revenues would have been mostly availability based. The approach would have increased the risk for the government in a certain way because revenues would have decreased. However, the government might have managed this risk by postponing future highway developments and using the revenues obtained for paying the commitments with the present concessionaires.

\section{REFERENCES}

1. Vassallo, J. M., and A. Sánchez-Soliño. Subordinated Public Participation Loans for Financing Toll Highway Concessions in Spain. In Transportation Research Record: Journal of the Transportation Research Board, No. 1996, Transportation Research Board of the National Academies, Washington, D.C., 2007, pp. 1-8.

2. Izquierdo, R., and J. M. Vassallo. Nuevos Sistemas de Gestión y Financiación de Infraestructuras de Transportes. Colegio de Ingenieros de Caminos, Canales y Puertos, Madrid, Spain, 2004.

3. Vassallo, J. M., and J. Gallego. Risk Sharing in the New Public Works Concession Law in Spain. In Transportation Research Record: Journal of the Transportation Research Board, No. 1932, Transportation Research Board of the National Academies, Washington, D.C., 2005, pp. 1-8.

4. Sánchez Soliño, A., and P. Gago. Transaction Costs in Transport PublicPrivate Partnerships: Comparing Procurement Procedures. Transport Reviews, Vol. 30, 2010, pp. 389-406.

5. Pinglo, M. A., J. L. Guasch, and V. Foster. How Profitable Are Private Infrastructure Concessions in Latin America? Empirical Evidence and Regulatory Implications. Quarterly Review of Economics and Finance, Vol. 45, 2005, pp. 380-402.

6. Transport Infrastructure Investment: Options for Efficiency. Organization for Economic Cooperation and Development, Joint Transport Research Centre, Paris, 2008.

7. Loosemore, M. Risk Allocation in the Private Provision of Public Infrastructure. International Journal of Project Management, Vol. 25, 2007, pp. 66-76.

8. Medda, F. A Game Theory Approach for the Allocation of Risks in Transport Public Private Partnerships. International Journal of Project Management, Vol. 25, 2007, pp. 213-218.

9. Global Development Finance. World Bank, Washington, D.C., 2007.

10. Rallo, J. R. Crónicas de la Gran Recesión. Unión Editorial, Madrid, Spain, 2011.

11. Banco de España. Boletín económico de Marzo del 2011. Madrid, Spain, 2011.

12. Bain, R. Error and Optimism Bias in Toll Road Traffic Forecasts Transportation, Vol. 36, 2009, pp. 469-482.

13. Ortega, A., M. A. Baeza, and J. M. Vassallo. Autopistas de peaje en los accesos a Madrid: ¿qué lecciones debemos aprender para el futuro? Revista de Obras Públicas, Vol. 3519, 2011, pp. 41-50.

14. Wagenvoort, R., C. de Nicola, and A. Kappeler. Infrastructure Finance in Europe: Composition, Evolution and Crisis Impact. EIB Papers, Vol. 15, No. 1, 2010, pp. 23-33.

15. Tena, A. La titulización de activos como instrumento para la financiación de Infraestructuras en España. Doctoral thesis. Universidad Politécnica de Madrid, Spain, 2011.

16. Vassallo, J. M. Flexible Term Highway Concessions: How Can They Work Better? In Transportation Research Record: Journal of the Transportation Research Board, No. 2187, Transportation Research Board of the National Academies, Washington, D.C., 2010, pp. 22-28.

17. Vassallo, J. M., and A. Sánchez-Soliño. Minimum Income Guarantee in Transportation Infrastructure Concessions in Chile. In Transportation Research Record: Journal of the Transportation Research Board, No. 1960, Transportation Research Board of the National Academies, Washington, D.C., 2006, pp. 15-22.

18. Vassallo, J. M., M. A. Baeza, P. Saldaña, and J. Sierra. Proyecto OASIS: Deliverable 1.2.2: Diseño de modelos concesionales integrales. Universidad Politécnica de Madrid, Spain, 2010.

19. Commission Staff Working Paper on the Europe 2020 Project Bond Initiative. European Commission, Brussels, Belgium, 2011.

20. TIFIA Report to Congress: Transportation Infrastructure Finance Act of 1998. U.S. Department of Transportation, 1998.

The Revenue and Finance Committee peer-reviewed this paper. 